\title{
KLASIFIKASI KOMPETENSI DIGITAL DOSEN BAHASA INGGRIS DI ERA PANDEMI
}

\author{
Yusup Supyani $\left(^{1)}\right.$ dan Deri Fikri F $\left(^{2)}\right.$ \\ ${ }^{1,2}$ Sastra Inggris, Universitas Putra Indonesia \\ 1,2 Jl. Dr. Muwardi No. 66 Bypass Cianjur 43215 \\ E-mail : yusup.supyani@gmail.com ${ }^{1)}$,dare.fikr@gmail.com ${ }^{2)}$
}

\begin{abstract}
ABSTRAK
Digitalisasi sekarang ini secara luas digunakan oleh semua pihak pemangku kebijakan di bidang pendidikan, termasuk level perguruan tinggi. Dosen yang memegang posisi yang penting dalam proses pembelajaran harus beradaptasi dengan baik pada teknologi informasi terbaru. Lambat laun, perkembangan teknologi akan memaksa semua pekerja untuk menggunakannya jika masih ingin bertahan di era ini. Di sisi lain, penyebaran Pandemi Covid-19 di seluruh dunia menuntut dosen dan mahasiswa untuk memaksimalkan penggunaan teknologi informasi terkini. Bagaimana dosen menggunakan perangkat digital dalam melaksanakan proses pembelajaran merupakan fokus inti dari studi ini. Studi ini bertujuan untuk memetakan kemampuan dosen dalam menggunakan perangkat digital dalam mendukung proses pembelajaran yang dilakukan. Selebihnya target dari studi ini adalah untuk memberikan sekilas penjabaran tentang kemampuan kompetensi digital kepada Lembaga Penjamin Mutu di kampus dan lebih jauh dapat memberikan pertimbangan yang komprehensif tentang bagaimana mengembangkan dan memandu kompetensi digital dosen di masa depan. Studi ini menggunakan penelitian kualitatif dengan partisipan 8 dari 11 dosen yang mengampu di Fakultas Sastra Universitas Putra Indonesia Tahun Akademik 2020/ 2021. Partisipan dalam studi ini 72\% adalah dosen yang mengampu mata kuliah Linguistik atau Sastra. Teknik pengumpulan data yang dilakukan dengan menggunakan metode triangulasi, observasi, dokumentasi, dan wawancara. Hasil studi mengungkapkan bahwa partisipan telah cakap dalam menggunakan digital sesuai standar perguruan tinggi dan lolos melewati semua kriteria kompetensi digital.
\end{abstract}

Kata Kunci: Kompetensi Digital, Digitalisasi Pembelajaran, Dosen Bahasa, Teknologi Informasi, Pandemi Covid-19

\section{PENDAHULUAN}

Pandemi Covid-19 telah menjadi masalah dunia yang belum dituntaskan. Covid-19 adalah penyakit infeksi yang disebabkan oleh Virus SARS-CoV-2. WHO kemudian mendeklarasikan fenomena ini sebagai masalah kesehatan darurat internasional pada tanggal 30 Januari 2020 (Hager dkk., 2020). Efek dari pandemi tersebut sebagaimana yang bisa kita lihat, semua pelaku pendidikan, yang didominasi oleh orang tua, 'dipaksa' untuk menggunakan teknologi informasi sebagai media pembelajaran (Daoust, 2020).

Sebelum pandemi, pembelajaran tentu mengandalkan tatap muka dan e-learning menjadi pendukung pembelajaran. Hal ini menjadi berubah secara drastis ketika pandemi, semua proses pembelajaran dari hulu ke hilir menjadi berbasis digital (Jana, 2021). Satu hal yang perlu diketahui bahwa tidak setiap dosen mengetahui dan menggunakan teknologi informasi sebagai media pembelajaran, di antara mereka ada yang masih jarang bahkan belum cakap sama sekali menggunakannya. Hal inilah yang membuat peneliti mencoba menelusuri lebih lanjut.

Pendidikan berbasis teknologi informasi dipandang sebagai cara dalam menyiapkan siswa menghadapi 'era informasi' dengan mengajarkan mereka keahlian dasar yang diperlukan nanti di dunia kerja (Fraillon dkk., 2014). Di samping itu 'kompetensi digital' digunakan dalam menjelaskan kemampuan dan pengetahuan yang dibutuhkan dalam menyiapkan siswa dalam persaingan global dan perkembangan karier mereka nanti. Saat ini, istilah tersebut mencakup juga keahlian 'interaksi komputer' seperti menggunakan keyboard dan perangkat lunak/ software dasar (Tyner, 2014).

Tentu saja ada banyak kelebihan dari sikap dosen dan mahasiswa yang menggunakan teknologi informasi dibanding yang tidak (OECD, 2017). Lebih jauh, penggunaan teknologi informasi tersebut dalam kehidupan akademik di kampus dapat berimplikasi pada peningkatan kualitas pendidikan secara umum. Di antara bukti yang mendukung hal tersebut adalah adanya kemudahan proses berkomunikasi antara dosen dan mahasiswa, kemudahan dalam mengakses informasi dan literatur, serta bertambahnya variasi penggunaan materi belajar (Goodfellow \& Lea, 2013).

Lee dalam penelitiannya menemukan bahwa peran dosen dalam menggunakan computer-assisted language learning telah terbukti dapat meningkatkan kemampuan outcome peserta didiknya. Peningkatan tersebut mencakup semua skills dalam Bahasa Inggris. (Lee, 2019). 
Secara umum, pembahasan tentang literasi teknologi informasi dan komunikasi telah ada. Kurnianingsih menemukan fakta bahwa masyarakat Sulawesi Selatan telah cakap dalam menggunakan teknologi informasi dalam mengakses informasi (Kurnianingsih dkk., 2017).

Penelitian lain ditemukan bahwa penggunaan teknologi informasi oleh siswa SMA tidak berbanding lurus antara perangkat teknologi informasi dengan alat bantu pembelajaran Bahasa Inggris (Suratno \& Aydawati, 2017).

Penelitian terakhir mengungkapkan bahwa ada hubungan yang signifikan antara pengetahuan tentang literasi digital dengan kemampuan menulis/ writing (Muthmainnah, 2019).

Secara harfiah, menurut kamus, literasi adalah kemampuan membaca dan menulis, sedangkan kompetensi berarti kemampuan melakukan sesuatu dengan baik dan efektif. Erstad menyatakan bahwa kompetensi merupakan istilah yang lebih komprehensif daripada keterampilan. Kompetensi meliputi aspek teknis yang terkait dengan manajemen perangkat keras/ hardware dan perangkat lunak/ software dan lebih banyak aspek kognitif yang terkait dengan pengetahuan dan pendidikan (Elstad \& Christophersen, 2017).

Literasi digital didefinisikan sebagai 'kemampuan individu yang tepat untuk hidup, belajar, dan bekerja dalam masyarakat digital'. Keterampilan dalam menggunakan teknologi oleh pengguna disebut sebagai 'alat netral' telah mengkonseptualisasikan kembali literasi digital, seperti literasi lainnya, sebagai praktek sosial dan budaya. Pendekatan 'kritis' terhadap literasi digital ini berfokus pada 'bagaimana makna dibangun, oleh siapa dan untuk tujuan apa' dan tantangan 'mencoba menyesuaikan praktik sosial budaya baru ke dalam konsepsi 'literasi'. Dalam praktiknya, literasi digital melibatkan individu yang membuat keputusan berdasarkan informasi tentang teknologi apa yang akan digunakan sesuai dengan kebutuhan dan praktik disiplin mereka (Kosnik dkk., 2016). Keterampilan ini berlaku umum bagi civitas akademika di institusi pendidikan. Bukan hanya Dosen yang cakap dalam menggunakannya, namun staf pendukung/middle management wajib menguasainya. (Newland \& Handley, 2016)

Prinsip yang penting dalam literasi digital adalah fakta bahwa kemampuan tersebut berhubungan langsung dengan individu. Sikap kita menggunakan system informasi berbanding lurus dengan sikap kita dalam menggunakannya. Keterampilan yang berhubungan dengan literasi digital dalam menggunakan teknologi informasi tidak sesederhana menemukan dan menyortir informasi, namun bagaimana mendapatkan pengalaman belajar yang bermakna dan mempertanggungjawabkan pengetahuan yang didapat dan disebarluaskan. (Goodfellow \& Lea, 2013).

Berbeda dengan penelitian-penelitian sebelumnya seperti yang disebutkan di atas, penelitian ini diharapkan dapat menjawab permasalahan yang baru. Topik baru yang diangkat dalam studi ini dapat dipisahkan dalam dua kategori inti, yang pertama penggunaan istilah yang berbeda, yaitu kompetensi digital (Elstad \& Christophersen, 2017) yang kedua membahas juga tentang bagaimana tenaga pengajar memberikan perkuliahan Bahasa Inggris, baik teori maupun praktik (Maloney, 2019).

Dosen Bahasa, termasuk Bahasa Inggris, haruslah cakap dalam mengajarkan keterampilan/skills, seperti mendengarkan/listening, membaca/reading, menulis/writing, dan berbicara/speaking. Berdasarkan kurikulum yang dipakai di institusi di mana penelitian ini dilaksanakan, skills tersebut dipecah menjadi dua konsentrasi, teori dan praktik. Di sisi lain, materi-materi yang sifatnya teoretis, terutama dalam rumpun linguistic dan sastra, Kegiatan ini menantang dosen untuk memiliki kompetensi yang baik dalam menyampaikan materi dengan perkembangan teknologi system informasi saat ini yang tentunya semua proses tersebut mengerucut pada kebijakan yang berlaku di Negara masing-masing, termasuk di Indonesia. (Havifah \& Yogyakarta, 2019)

\section{RUANG LINGKUP}

Untuk memperjelas masalah yang akan dibahas dan agar tidak terjadi pembahasan yang meluas dan menyimpang maka perlu kiranya dijelaskan ruang lingkup pada penelitian ini. Adapun ruang lingkup dalam penelitian ini adalah bagaimana mengklasifikasi kompetensi digital dosen di Fakultas Sastra Universitas Putra Indonesia. Penelitian ini diharapkan dapat memetakan kompetensi dosen dalam digitalisasi pembelajaran, khususnya selama masa pandemi Covid19 dan dapat memberikan kontribusi dalam menyiapkan dosen terkait kemampuan teknologi informasi.

\section{BAHAN DAN METODE}

Pada bagian ini akan dijelaskan bahan-bahan dan metode apa yang akan digunakan dalam penelitian ini, di antaranya:

\subsection{Kompetensi Digital}

Krumsvik memberikan definisi kompetensi digital khusus untuk dosen bahwa kompetensi digital itu adalah kemampuan dosen untuk menggunakan teknologi informasi dengan pemahaman yang baik tentang teknologi informasi pedagogis-didaktik dan menyadari bagaimana hal ini dapat berdampak pada strategi pembelajaran dan pembentukan pendidikan mahasiswa (Elstad \& Christophersen, 2017). Definisi tersebut mengindikasikan bahwa dari sejak awal setiap dosen harus mengetahui dan menentukan perangkat digital apa yang akan digunakan dalam pembelajaran.

Secara garis besar, penelitian ini mengacu pada teori dari Ottestad yang dikutip dalam Elstad yang mengemukakan tiga dimensi utama dalam menggambarkan kompetensi digital dosen dalam melaksanakan pembelajaran: 
1. Kompetensi Digital Generik (Generic Digital Competence)

Kompetensi ini menunjukkan pengetahuan dan keterampilan umum yang harus dimiliki dosen agar dapat berfungsi sebagai pendidik digital. Dimensi ini identik dengan deskripsi kompetensi digital secara umum, seperti kemampuan mengoperasikan komputer, mengarsipkan file, dan lain-lain.

2. Kompetensi Didaktik Digital (Digital Didactic Competence)

Dimensi kompetensi ini merefleksikan kecakapan digital yang khusus dalam setiap mata kuliah yang dipegang oleh setiap dosen pengajar. Dalam dimensi inilah perbedaan khas yang sebenarnya dalam didaktik antara mata kuliah akan dijelaskan, misalnya, matematika yang diajarkan melalui teknologi informasi dibandingkan dengan bahasa asing atau pedagogi yang diajarkan melalui TIK. Dalam dimensi ini dosen dituntut berkreasi dan memodifikasi proses/ perangkat pembelajaran yang disesuaikan dengan materi yang dipegangnya.

3. Kompetensi Digital Berorientasi Profesional (Professional-oriented Digital Competence)

Kompetensi ini menggambarkan karakteristik digital yang diperluas dari profesi dosen. Kompetensi ini berkutat tentang apa yang dibutuhkan dosen literasi digital, misalnya ketika mereka merencanakan pelajaran mata pelajaran, menyortir evaluasi, memberikan tugas, berkomunikasi dengan mahasiswa atau wali, dan lain-lain (Elstad \& Christophersen, 2017). Dimensi ini menuntut lebih komprehensif peran dosen, dimulai dari perencanaan, pelaksanaan, sampai evaluasi pembelajaran dengan perangkat yang tepat. Lebih jauh, peran dosen dituntut lebih cakap dalam berkomunikasi secara digital dengan pihak-pihak yang terkait selama proses pembelajaran dilaksanakan, misalnya dengan mahasiswa dan teman sejawat.

Di sisi lain, UNESCO memberikan kerangka untuk mendeskripsikan kompetensi digital dosen dengan menguraikan berbagai aspek keterampilan digital dosen dan tingkat kemahiran di dalamnya. Aspek-aspek tersebut adalah a) kebijakan dan kerangka kerja, b) kurikulum dan penilaian, c) pedagogi, d) pengetahuan dan keterampilan, e) lingkungan belajar dan administrasi, dan f) pengembangan pribadi dan pemahaman profesional (Tyner, 2014).

Dalam penelitian ini, dimensi-dimensi tersebut dijabarkan ke dalam indikator-indikator khusus yang diterapkan pada partisipan melalui kuesioner. Ada 20 (dua puluh) pertanyaan dalam kuesioner penelitian ini. Adapun dokumentasi diambil dari berkas-berkas yang diambil dari program studi, di antaranya RPS, soal UTS, soal UAS, dan nilai akhir mahasiswa. Sementara observasi, penulis melakukan sit in di kelas secara acak guna mendapatkan penilaian yang komprehensif.

\subsection{Digitalisasi Pembelajaran}

Konten digital masuk di hampir seluruh sendi kehidupan kita saat ini, termasuk dalam bidang pendidikan. Mulai dari artikel berita yang kita baca di pagi hari sampai cerita dongeng anak sebelum tidur kita dapatkan dari perangkat/ gadget, yang intinya adalah kita mengakses informasi apapun secara digital. Hal tersebut berimplikasi pada dunia pendidikan yang tentu saja kena imbas dari perubahan perilaku manusia dalam menggunakan teknologi informasi tersebut. Mizuho berpendapat bahwa guru/ dosen haruslah menguasai materi yang telah terintegrasi ke dalam kondisi belajar yang berbeda secara digital (Iinuma, 2018). Hal tersebut lumrah terjadi belakangan ini mengingat pandemi covid19 yang mengharuskan dosen berkreasi mengikuti ritme kebutuhan teknologi informasi saat ini.

Lund dkk. berpendapat bahwa penggunaan teknologi digital dalam pendidikan, guru harus dapat mempromosikan proses konstruksi pengetahuan mahasiswa di kelas. Dengan kata lain mahasiswa perlu belajar bagaimana mengubah pengetahuan teoretis mereka menjadi didactic yang khusus tentang mata kuliah, manajemen kelas, dan penilaian tentang bagaimana mereka memanfaatkan sumber daya yang tersedia secara produktif (Elstad \& Christophersen, 2017).

Manfaat yang dapat dirasakan dari pembelajaran berbasis digital adalah bahwa materi dan sumber daya pengajaran dan pembelajaran digital lebih mudah dibagikan dan digunakan kembali daripada versi cetak/ tradisional (Goodfellow \& Lea, 2013). Implikasinya kita disuguhkan pada kondisi ketersediaan informasi yang utuh yang nantinya akan menuntut kita untuk bijak memilah informasi yang tepat dan benar. Hal ini yang dikemukakan oleh T. Susman dalam menggunakan media digital saat ini (Susman-peña dkk., 2020).

Fakta lain juga menunjukkan bahwa perkembangan mesin pencari/ search engine telah membuat kita dapat mencari dan menemukan informasi yang kita butuhkan. Seiring dengan hal tersebut, diperlukan keterampilan individu dalam menggunakannya. Faktor individu yang lahir di tahun 1990-an adalah individu yang mengalami lonjakan penggunaan teknologi informasi yang sangat pesat. Generasi tersebut disebut sebagai penduduk asli digital/ 'digital residents' dan generasi Google (Huvila, 2012).

\subsection{Gambaran Umum}

Secara khusus penelitian ini membahas tentang kompetensi dosen dalam melaksanakan perkuliahan secara online selama pandemi Covid-19. Pandemi Covid19 memaksa insan pendidikan untuk segera dapat beradaptasi dengan beragam variasi pembelajaran yang ada. Paradigma pembelajaran pun ikut berubah, dari 
prinsip bahwa teknologi hanyalah sebuah opsi dalam melaksanakan pembelajaran menjadi sebuah keharusan dalam dunia pendidikan (Hager dkk., 2020)

Pandemi Covid-19 secara tidak langsung mempengaruhi perilaku dosen dan mahasiswa. Contoh yang paling nyata adalah fleksibilitas belajar yang semakin membesar dan diminati mahasiswa. Perubahan lainnya mengakibatkan proses pembelajaran secara umum membutuhkan penyesuaian dari semua sudut pandang. Implikasi dari pandemi Covid-19 secara lengkap dapat dilihat dalam gambar 1 .

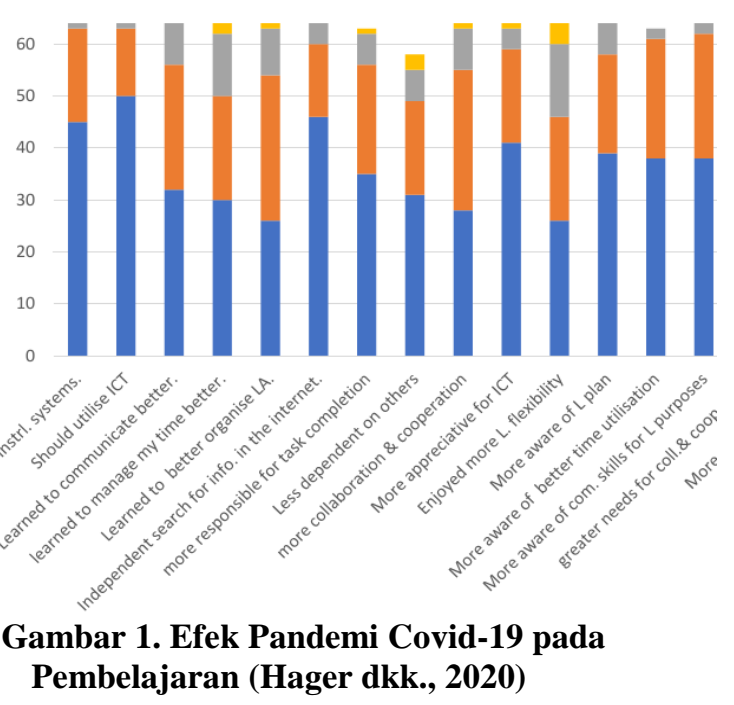

Efek lain yang cukup serius pada kesehatan mental peserta didik di antaranya adalah mereka lebih mudah stress dan depresi saat lockdown karena Pandemi Covid19 ini dibandingkan saat sebelumnya (Elmer dkk., 2020). Hal ini mau tidak mau harus dipertimbangkan oleh dosen/ guru dalam upaya memberikan ketenangan dalam mengikuti pembelajaran, bukan malah sebaliknya.

Dalam penelitian ini, analisis data dilakukan secara deskriptif. Data yang telah diperoleh dikelompokkan, disajikan dalam bentuk data yang mudah dibaca, kemudian dianalisis dan disimpulkan. Studi ini akan memetakan kompetensi mereka dalam menggunakan teknologi informasi selama kegiatan mereka dari perencanaan hingga evaluasi. Partisipan dari penelitian ini diambil dari dosen-dosen Bahasa Inggris yang mengampu di Fakultas Sastra Universitas Putra Indonesia, yang tentu saja berurusan dengan bahasa.

Klasifikasi kompetensi digital, seperti yang tertera di bagian sebelumnya, akan diuraikan ke dalam 3 jenis teknik pengumpulan data, yaitu observasi, wawancara, dan telaah dokumen. Adapun urutan kegiatan pengumpulan data dapat dilihat dalam gambar 2 .

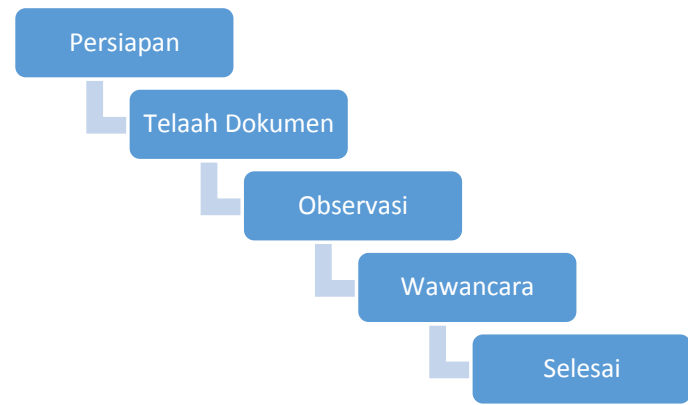

Gambar 2. Alur Pengumpulan Data

\subsection{Partisipan}

Partisipan dalam penelitian ini diambil dari dosen yang mengampu mata kuliah di Fakultas Sastra Universitas Putra Indonesia yang identitasnya dapat dilihat dalam tabel 1.

Tabel 1. Data Partisipan

\begin{tabular}{|l|l|l|l|}
\hline No & Inisial Partisipan & \multicolumn{1}{|c|}{ Status } & \multicolumn{1}{|c|}{ Umur } \\
\hline 1 & TL & Dosen Tetap & $\begin{array}{l}31-40 \\
\text { tahun }\end{array}$ \\
\hline 2 & RTU & Dosen Tetap & $\begin{array}{l}31-40 \\
\text { tahun }\end{array}$ \\
\hline 3 & MN & $\begin{array}{l}\text { Dosen Luar } \\
\text { Biasa }\end{array}$ & $\begin{array}{l}41-50 \\
\text { tahun }\end{array}$ \\
\hline 4 & ARN & $\begin{array}{l}\text { Dosen Luar } \\
\text { Biasa }\end{array}$ & $\begin{array}{l}20-30 \\
\text { tahun }\end{array}$ \\
\hline 5 & IL & Dosen Tetap & $\begin{array}{l}31-40 \\
\text { tahun }\end{array}$ \\
\hline 6 & LKY & Dosen Tetap & $\begin{array}{l}41-50 \\
\text { tahun }\end{array}$ \\
\hline 7 & SEC & $\begin{array}{l}\text { Dosen Luar } \\
\text { Biasa }\end{array}$ & $>51$ tahun \\
\hline 8 & TA & $\begin{array}{l}\text { Dosen Luar } \\
\text { Biasa }\end{array}$ & $\begin{array}{l}31-40 \\
\text { tahun }\end{array}$ \\
\hline
\end{tabular}

\subsection{Metode}

Penelitian Klasifikasi Kompetensi Digital Dosen Bahasa Inggris di Era Pandemi menggunakan metode deskriptif kualitatif. Penelitian kualitatif merupakan penelitian yang fokus pada pertanyaan penelitian yang terkait dengan pertanyaan siapa, apa, di mana, dan bagaimana suatu peristiwa yang terjadi (Kim, dkk, 2017). Dalam penelitian ini, data diambil dari pembelajaran di Fakultas Sastra Universitas Putra Indonesia selama masa pandemic Covid-19. Tahapan pengumpulan dan analis data dilakukan melalui 3 tahap, yaitu:

1. Detection

Tahap ini konten dan dimensi dari sebuah fenomena diidentifikasi.

2. Categorization

Tahap ini menyaring dan menempatkan data deskriptif dari temuan di lapangan.

3. Classification

Tahap ini mengelompokkan temuan data ke dalam kelas-kelas kelompok (teori) yang telah disediakan sebelumnya (Ritchie, 2003). 
Setelah melaksanakan ketiga tahap kemudian dilanjutkan dengan menganalisis kompetensi digital dosen dalam 3 jenis dimensi, Generic Digital Competence, Digital Didactic Competence, dan Professional-oriented Digital Competence.

\section{PEMBAHASAN}

Terdapat dua kompetensi digital yang akan dibahas, yaitu kompetensi digital generik dan didaktik.

\subsection{Kompetensi Digital Generik}

Kompetensi tersebut meliputi observasi dan angket. Observasi diambil dari penggunaan media pembelajaran sedangkan wawancara diwakili oleh 4 pertanyaan. Temuan dari hasil tersebut dapat dilihat pada gambar 3

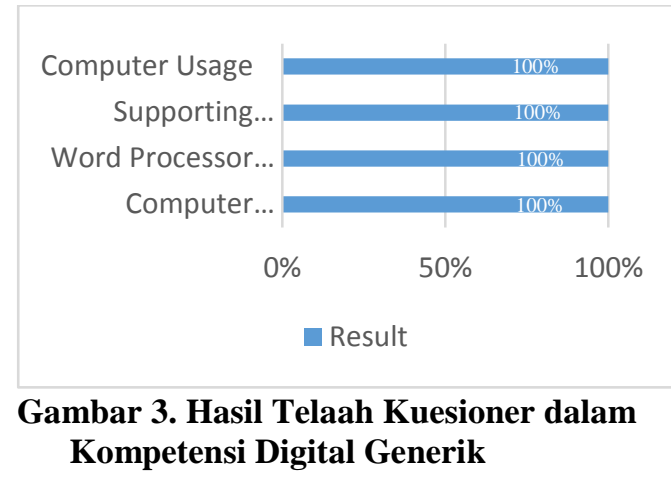

Dari gambar 3 ditemukan bahwa keempat indikator dalam kompetensi pertama ini semua dosen telah mencapai angka $100 \%$. Indikator penggunaan komputer, penggunaan software computer, word processor, dan variasi teknik penggunaan teknologi informasi telah terbukti bisa dan terbiasa dilakukan oleh semua partisipan. Hasil analis observasi dalam Kompetensi Digital Generik dapat disimak di gambar 4.

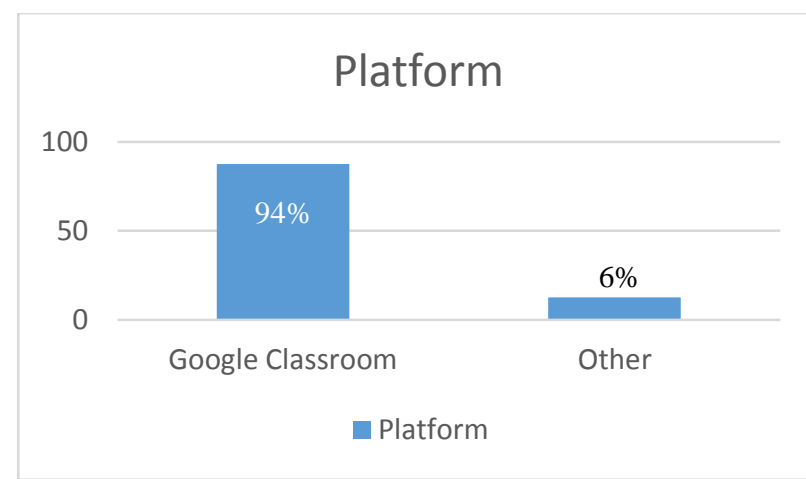

\section{Gambar 4. Hasil Telaah Observasi dalam Kompetensi Digital Generik}

Berdasarkan grafik hasil observasi di atas ditemukan bahwa hampir semua dosen (94\%) telah menggunakan Google Classroom dalam pembelajaran daring. Penggunaan Google Classroom menunjukkan bahwa partisipan telah cakap dalam mengelola pembelajaran daring. Sisanya $(6 \%)$ dosen menggunakan aplikasi Edmodo sebagai LMS (Learning Management System) dalam melaksanakan pembelajaran nya.

Kedua hasil analis di atas membuktikan bahwa partisipan dipandang cakap/ berkompeten pada tipe ini, dengan kata lain kompetensi ini dikuasai dengan baik oleh semua dosen.

\subsection{Kompetensi Digital Didaktik}

Kompetensi tersebut meliputi dokumen, observasi, dan angket. Dokumen diambil dari jenis tugas yang diberikan kepada mahasiswa, sedangkan observasi diambil dari berbagai penggunaan media pembelajaran oleh dosen, dan wawancara diwakili oleh 3 pertanyaan. Temuan dari hasil tersebut dapat dilihat pada gambar 5 .

Hasil telaah dokumen pada Kompetensi Digital Didaktik dapat dilihat pada gambar 5.

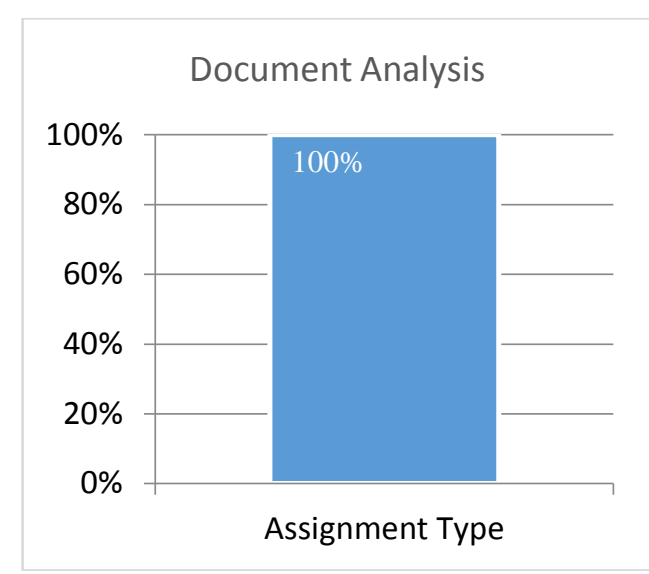

\section{Gambar 5. Hasil Dokumen dalam Kompetensi Didaktik Digital}

Gambar 5 menunjukkan bahwa semua jenis tugas yang diberikan dan dikumpulkan telah sesuai dengan format yang ditentukan oleh program studi. Format yang ditentukan oleh Prodi bahwa semua tugas dari mata kuliah teori dapat dikirim melalui email, Google form, Google classroom, ataupun LMS yang diakui Prodi. Semua partisipan telah menggunakan format yang ditentukan. Adapun hasil telaah observasi dalam Kompetensi Didaktik Digital sebagaimana tertera di gambar 6.

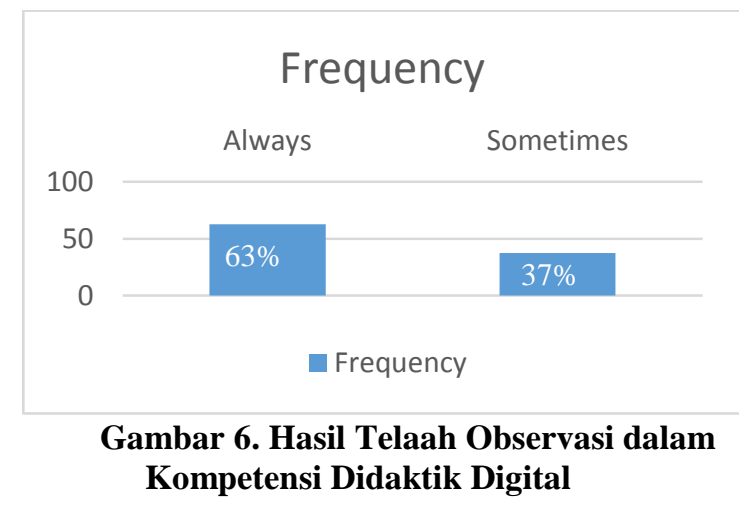


Gambar 6 adalah hasil telaah tentang metode pembelajaran, apakah dosen melakukan penyesuaian metode pembelajaran dengan mata kuliah yang dipegang atau tidak. Hasil yang tampak menunjukkan bahwa $63 \%$ partisipan selalu menggunakan variasi metode pembelajaran yang berbeda yang disesuaikan dengan mata kuliah yang dipegang. Contohnya, mata kuliah listening diperlukan perangkat pendukung, materi, dan pengumpulan tugas yang berbeda dengan mata kuliah structure. Sisanya $45 \%$ partisipan kadang menggunakan variasi metode pengajaran yang disesuaikan dengan mata kuliah yang dipegang. Hasil ini menunjukkan bahwa lebih dari setengah partisipan telah menguasai kompetensi ini. Adapun hasil telaah kuesioner dalam kompetensi Didaktik Digital sebagaimana nampak di gambar 7.

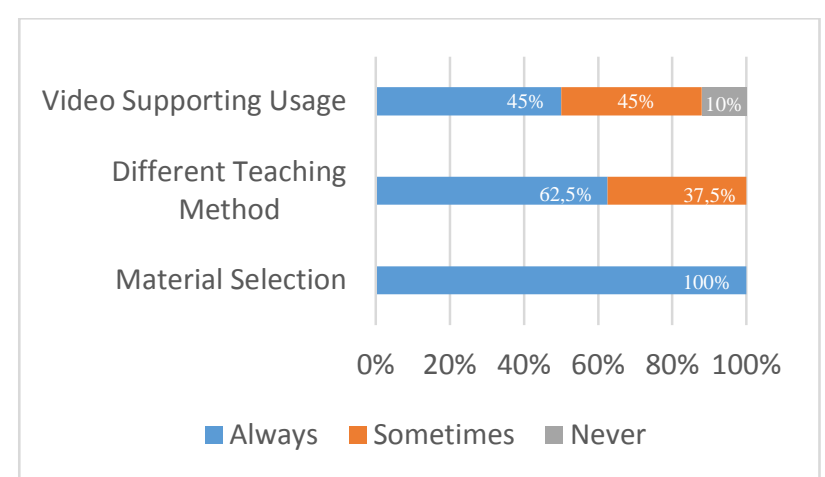

\section{Gambar 7. Hasil Telaah Kuesioner dalam Kompetensi Didaktik Digital}

Gambar 7 adalah hasil angket yang merujuk kepada tiga indikator dalam kompetensi ini, kemampuan memilih materi, penggunaan metode pengajaran yang bervariasi, dan penggunaan dukungan video dalam pembelajaran. Dari hasil telaah kuesioner, didapatkan sebanyak rata-rata $72,3 \%$ partisipan telah memenuhi kriteria dalam Kompetensi Didaktik Digital.

Setelah dilakukan cross cutting di antara ketiga cara penggalian data tersebut didapatkan hasil bahwa sebanyak hampir semua partisipan telah berhasil mencapai kompetensi ini.

Kompetensi Digital Berorientasi Profesional

Kompetensi ini meliputi dokumen, observasi, dan angket seperti kompetensi sebelumnya. Dokumen diambil dari RPP yang dibuat oleh dosen dan format nilai akhir yang sesuai dengan ketentuan Prodi, sedangkan observasi dianalisis dari metode dan media yang digunakan dosen dan mahasiswa. Wawancara diwakili oleh 3 pertanyaan, kompetensi mengakses referensi dari internet, kompetensi mencari bahan/sumber, dan kompetensi membuat RPS secara online. Temuan dari hasil tersebut dapat dilihat pada gambar 8 .

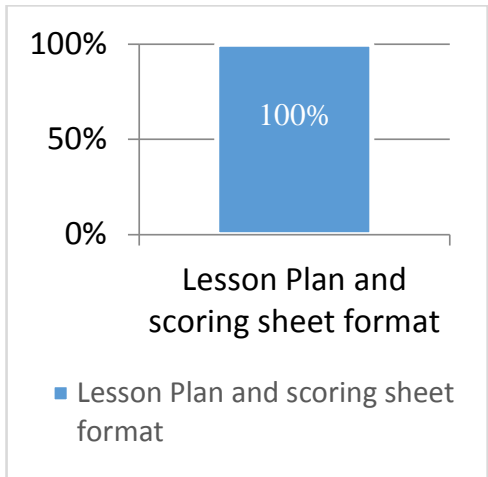

\section{Gambar 8. Hasil Telaah Dokumen dalam Kompetensi Digital berorientasi Profesional}

Analisis dokumen menunjukkan bahwa semua dosen telah lulus persyaratan yang ditetapkan oleh prodi. Prodi telah mengatur format RPS dengan cara tertentu sedangkan lembar penilaian akhir diwajibkan dalam format tertentu. Hasil telaah observasi dalam Kompetensi Digital berorientasi Profesional dapat dilihat di gambar 9.

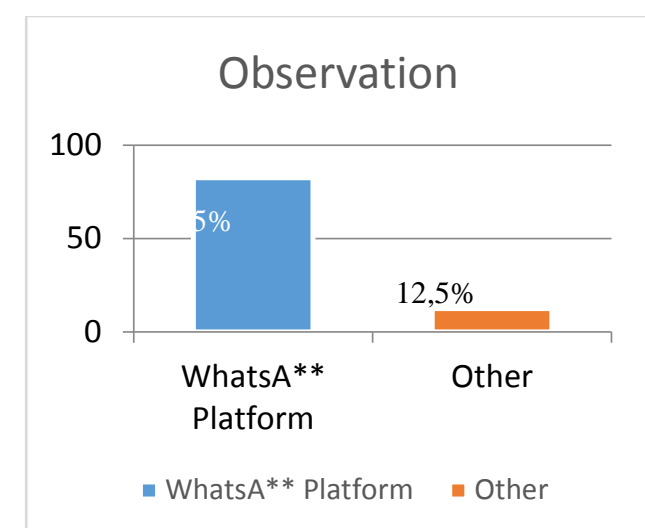

Gambar 9. Hasil Telaah Observasi dalam

Kompetensi Digital berorientasi Profesional

Hasil telaah observasi menunjukkan bahwa sebagian besar dosen $(87,5 \%)$ telah menggunakan media online untuk berkomunikasi melalui platform Whatsapp. Artinya mereka memiliki kompetensi berkomunikasi secara online dengan menggunakan platform paling banyak digunakan saat ini.

Hasil telaah wawancara dalam Kompetensi Digital berorientasi Profesional dapat dilihat pada gambar 10 . 


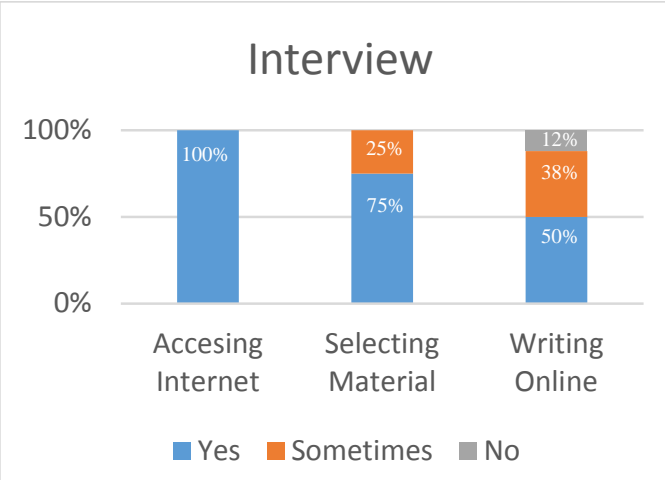

Gambar 10. Hasil Wawancara dalam Kompetensi Digital berorientasi Profesional

Data terakhir, yang didapatkan melalui kuesioner, menunjukkan bahwa separuh dosen (50\%) pernah membuat RPS secara online (menggunakan google docs), sementara beberapa dosen (38\%) kadang-kadang melakukannya. Dari ketiga penggalian data di atas ditemukan bahwa sebagian besar partisipan memiliki kompetensi digital berorientasi profesional.

\section{KESIMPULAN}

Hasil dari analis data menunjukkan bahwa partisipan telah melampaui indikator-indikator dalam semua dimensi kompetensi, baik kompetensi digital generik, didaktik, maupun berorientasi profesional dengan persentase rata-rata pencapaian sebesar $84,9 \%$.

\section{SARAN}

Penelitian ini hanya baru sampai tahap memetakan kompetensi digital dosen dalam satu rumpun ilmu saja, yaitu rumpun Ilmu Bahasa. Diperlukan pemetaan kompetensi digital kepada dosen yang mengampu dalam rumpun ilmu yang lainnya agar didapatkan kesimpulan yang lebih umum dan komprehensif.

\section{DAFTAR PUSTAKA}

Daoust, J. F. (2020). Elderly people and responses to COVID-19 in 27 Countries. PLoS ONE, 15(7), 113. https://doi.org/10.1371/journal.pone.0235590

Elmer, T., Mepham, K., \& Stadtfeld, C. (2020). Students under lockdown: Comparisons of students' social networks and mental health before and during the COVID-19 crisis in Switzerland. PLoS ONE, $15(7$ July), $1-22$. https://doi.org/10.1371/journal.pone.0236337

Elstad, E., \& Christophersen, K. A. (2017). Perceptions of digital competency among student teachers: Contributing to the development of student teachers' instructional self-efficacy in technologyrich classrooms. Education Sciences, 7(1). https://doi.org/10.3390/educsci7010027

Fraillon, J., Ainley, J., Schulz, W., Friedman, T., \& Gebhardt, E. (2014). Preparing for Life in a Digital Age. In Preparing for Life in a Digital Age. https://doi.org/10.1007/978-3-319-14222-7

Goodfellow, R., \& Lea, M. R. (2013). Literacy in the digital university: Critical perspectives on learning, scholarship, and technology. Literacy in the Digital University: Critical Perspectives on Learning, Scholarship, and Technology, 1-215. https://doi.org/10.4324/9780203074510

Hager, E., Odetokun, I. A., Bolarinwa, O., Zainab, A., Okechukwu, O., \& Al-Mustapha, A. I. (2020). Knowledge, attitude, and perceptions towards the 2019 Coronavirus Pandemic: A bi-national survey in Africa. PLoS ONE, $15(7$ July), 1-13. https://doi.org/10.1371/journal.pone.0236918

Havifah, B., \& Yogyakarta, U. N. (2019). Kebijakan pendidikan bahasa asing di Indonesia dalam perspektif masyarakat global. February. https://doi.org/10.21831/jppfa.v6i1.20612

Huvila, I. (2012). Information services and digital literacy. In Information Services and Digital Literacy. $\quad$ https://doi.org/10.1016/b978-1-84334683-8.50003-3

Iinuma, M. (2018). Learning and Teaching with Technology in the Knowledge Society: New Literacy, Collaboration and Digital Content. In Business Systems Research (Vol. 9, Issue 1). http://link.springer.com.conricyt.remotexs.co/conte nt/pdf/10.1007\%2F978-981-10-0144-4.pdf

Jana, P. (2021). E - Learning During Pandemic Covid-19 Era Drill Versus Conventional Models. International Journal of Engineering Pedagogy (IJEP), $\quad$ Vol 11 (No 3), 54-70. https://doi.org/doi.org/10.3991/ijep.v11i3.16505

Kim, H., Sefcik, J. S. and Bradway, C. 2017 "Characteristics of Qualitative Descriptive Studies: A Systematic Review", Journal of Career and Technical Education, 21(1), pp. 51-70. doi: 10.1002/nur.21768.Characteristics

Kosnik, C., White, S., Beck, C., Marshall, B., Lin Goodwin, A., \& Murray, J. (2016). Building bridges: Rethinking literacy teacher education in a digital era. In Building Bridges: Rethinking Literacy Teacher Education in a Digital Era. https://doi.org/10.1007/978-94-6300-491-6

Kurnianingsih, I., Rosini, R., \& Ismayati, N. (2017). Upaya Peningkatan Kemampuan Literasi Digital Bagi Tenaga Perpustakaan Sekolah dan Guru di Wilayah Jakarta Pusat Melalui Pelatihan Literasi Informasi. Jurnal Pengabdian Kepada Masyarakat (Indonesian Journal of Community Engagement), 3(1), 61. https://doi.org/10.22146/jpkm.25370

Lee, J. S. (2019). Quantity and diversity of informal digital learning of English. Language Learning and Technology, 23(1), 114-126. https://doi.org/10.125/44675

Maloney, J. (2019). Review of Language teacher education and technology: Approaches and practices. 23(1), 44-48.

Muthmainnah, N. (2019). A Correlational Study of 
Digital Literacy Comprehension Toward Students' Writing Originality. Langkawi: Journal of The Association for Arabic and English, 5(1), 45. https://doi.org/10.31332/lkw.v5i1.1151

Newland, B., \& Handley, F. (2016). Developing the digital literacies of academic staff: An institutional approach. Research in Learning Technology, 24(1063519),

$1-12$. https://doi.org/10.3402/rlt.v24.31501

OECD. (2017). Skills for a Digital World: Ministerial Meeting on the Digital Economy, Background Report 2016. OECD Digital Economy Papers, 250, 67.

Ritchie, Jane et al. (2003). QUALITATIVE A Guide for (J. Ritchie, Jane; Lewis (Ed.)). SAGE Publications, Inc.

Suratno, A., \& Aydawati, E. N. (2017). Exploring
Students Perception and ICT Use in Indonesian High Schools. Celt: A Journal of Culture, English Language Teaching \& Literature, 16(2), 177. https://doi.org/10.24167/celt.v16i2.735

Susman-peña, T., Druckman, M., \& Oduro, N. (2020). Fighting Misinformation: Digital Media Literacy. 80.

Tyner, K. (2014). Teaching and learning in the age of information. Literacy in a Digital World. https://www.taylorfrancis.com/books/9781135690 854

\section{UCAPAN TERIMA KASIH}

Kami haturkan terima kasih kepada semua pihak yang telah membantu peneliti dalam melakukan penelitian ini.

Penelitian ini dibiayai sepenuhnya oleh Kementerian Riset Teknologi dan Pendidikan Tinggi. 